\title{
Childhood Ovarian Embryonal Carcinoma
}

National Cancer Institute

\section{Source}

National Cancer Institute. Childhood Ovarian Embryonal Carcinoma. NCI Thesaurus.

Code C6546.

An embryonal carcinoma that arises from the ovary and occurs in children. 